\title{
KINETICS OF SUBSTITUTION OF CIS-BIS(MALONATO)DIAQUOCHROMATE(III) WITH GLYCINE, DL-ALANINE AND DL-PHENYLALANINE
}

\author{
Venkata Subba Rao Mushini ${ }^{1 *}$, V. Ananta Ramam ${ }^{2}$ and V. Muralidhara Rao ${ }^{2}$ \\ ${ }^{1}$ Department of Chemistry, G.M.R. Institute of Technology, Rajam 532 127, Andhra Pradesh, \\ India \\ ${ }^{2}$ School of Chemistry, Andhra University, Visakhapatnam 530 003, Andhra Pradesh, India
}

(Received August 4, 2008; revised April 26, 2009)

\begin{abstract}
The kinetics of interaction between amino acids such as glycine, DL-alanine and DLphenylalanine and cis-bis(malonato)diaquochromate(III) has been studied spectrophotometrically as a function of [glycine], [DL-alanine] and [DL-phenylalanine]. The effect of $\mathrm{pH}$, temperature and substrate is also studied. The substrate exists predominantly as the diaquospecies and amino acids (glycine, DL-alanine and DL-phenylalanine) as the zwitterion at the experimental conditions. The substitution reaction has been found to proceed via two steps: amino acid dependent and amino acid independent paths indicating that the substitution reaction occurs through associative interchange $\left(I_{a}\right)$ mechanism in the amino acid dependent path and the dissociative mechanism in the independent path, showing the higher reactivity of single ended malonate complex.
\end{abstract}

KEY WORDS: Substitution, cis-bis(malonato)diaquochromate(III), Amino acids

\section{INTRODUCTION}

The substitution reactions of the oxalato complexes of chromium(III) have been reviewed by Krishnamurthy [1]. However, very few papers have been published on the kinetics of $\mathrm{Cr}\left(\mathrm{C}_{2} \mathrm{O}_{4}\right)_{2} \mathrm{X}_{2}^{\mathrm{n}-}$ moiety; where $\mathrm{X}$ is any monodentate ligand other than water [2-6].

Amino acids are organic molecules that constitute a most important part of biological structure and body chemistry. In the amino acids, the amino group is basic portion of the molecule and it is capable of reacting with both organic and inorganic acids to form salts, amide, while the acid proton is capable of reacting with bases. At isoelectric $\mathrm{pH}$ the amino acid exists as a neutral species and exists as an ion pair. The derivatives of amino acids are generally hormones or chemotherapeutical reagents. The study of the reactions of amino acids serves as a model to understand the complex nature of the biological macromolecules in the metabolic process.

Several workers [7-11] reported on the study of chromium(III) complexes as deficiency of chromium(III) ion results in an impairment of intravenous glucose tolerance and diabetics like symptoms in man and animals. Chromium(III) metabolism is disrupted in diabetics, and its level in urine is double than that of in normal subjects [12]. Clinical trials though limited have shown favorable response to chromium(III) administration. The biological and nutritional role of chromium in plants and animals is a topic of current interest.

Banerjea and Dutta Choudhari [13] identified that the bond formation by glycine takes place simultaneously with the rupture of the $\mathrm{Cr}^{-} \mathrm{OH}_{2}$ bond in the kinetics of reaction of hexaaquochromium(III) with glycine. Khan and Kabir-ud-din [14] reinvestigated this reaction and suggested an associative interchange mechanism with a kinetic evidence for the formation of ion pair. In the $\mathrm{pH}$ range (3.0 to 3.8) tetra aquaglycinato chromium(III) complex [15] is formed in the reaction between glycine and chromium(III). In the anation study of mono (oxalato)tetraquochromium(III) with glycine, a glycine dependent path and glycine independent path representing an associative interchange $\left(I_{a}\right)$ mechanism and dissociative inter change $\left(I_{d}\right)$

*Corresponding author. E-mail: srmushini@yahoo.com 
mechanism is suggested by Subrahmanyam and Ananta Ramam [16]. A dissociate mechanism is proposed by Ramasami [17] in the kinetics of $\mathrm{Cr}\left(\mathrm{NH}_{3}\right)_{5} \mathrm{H}_{2} \mathrm{O}^{3+}$-glycine reaction, $\mathrm{Cr}-\mathrm{OH}_{2}$ bond breaking is a dominant factor in this investigation.

Niogy and De [18] noticed that the rate of anation by alanine is much faster than that isotopic water exchange and other anation processes, in the kinetics of substitution of aquo ligand from hydroxopentaaquochromium(III) by DL-alanine, and also studied the anation reaction [19] with DL-phenylalanine. Mitra and De [20, 21] observed both bond breaking and bond making are significant and proposed an $I_{a}$ mechanism in the kinetics of anation reaction of cis-diaquo-bis oxalatochromate(III) ion by DL-alanine and DL-phenylalanine .

Several workers [22-26] have reported the kinetic reactions of hexaaquochromium(III) with different amino acids. Subba Rao [27] observed the amino acid dependent and amino acid independent paths in the reaction of kinetics of substitution of cisbis(oxalato)diaquochromate(III) with amino acids such as glycine, DL-alanine and DLphenylalanine in acid medium. Basing on the available reported literature data of kinetics of substitution of chromium(III) complexes with amino acids, here an attempt is made to study the kinetics of substitution of malonato complexes of chromium(III) with glycine, DL-alanine and DL-phenylalanine. In the present communication the results relating to the formation of chromium(III)-amino acid complex from cis-bis(malonato)diaquochromate(III) and amino acids in acid medium are reported.

\section{EXPERIMENTAL}

The potassium salt of cis-bis(malonato)diaquochromate(III) was prepared by the reported [28] method, and its purity was confirmed by analysis [29]. The complex was analysed for chromium and malonate. Chromium was determined by oxidizing chromium(III) to chromium(VI) with alkaline $\mathrm{H}_{2} \mathrm{O}_{2}$ and titrating the later with standard $\mathrm{Fe}^{2+}$. Malonate [29] was estimated by extensive oxidation with chromium(VI). $2 \mathrm{~mL}$ of $5.0 \times 10^{-2} \mathrm{M}$ solution of cis-bis(malonato)diaquochromate(III) complex and $10 \mathrm{~mL}$ of $1.0 \mathrm{M}$ sodium hydroxide solution was taken and it was diluted to $50 \mathrm{~mL}$ and heated gently for a few minutes. The chromium hydroxide formed was filtered off and the contents were reduced to $10 \mathrm{~mL}$ by evaporation. To this $20 \mathrm{~mL}$ of concentrated sulfuric acid and $10 \mathrm{~mL}$ of $0.05 \mathrm{M}$ potassium dichromate were added and heated on a steam bath for two hours. The reaction mixtures were cooled to room temperature and 5 $\mathrm{mL}$ of concentrated phosphoric acid was added and the unreacted chromium(VI) was titrated with standard $\mathrm{Fe}^{2+}$. The chromium to malonate ratio was found to be 2.02 . Other method was also followed to confirm the purity of the synthesized complex. The visible absorption spectrum of the synthesized metal complex showed maxima at $415 \mathrm{~nm}\left(\varepsilon=41.6 \mathrm{M}^{-1} \mathrm{~cm}^{-1}\right)$ and $570 \mathrm{~nm}(\varepsilon$ $\left.=48.8 \mathrm{M}^{-1} \mathrm{~cm}^{-1}\right)$ as against reported [28] maxima at $417 \mathrm{~nm}\left(\varepsilon=41.4 \mathrm{M}^{-1} \mathrm{~cm}^{-1}\right)$ and $566 \mathrm{~nm}(\varepsilon=$ $\left.49.9 \mathrm{M}^{-1} \mathrm{~cm}^{-1}\right)$. All other chemicals used were of reagent grade. Triple distilled water was used to prepare all the solutions. The product of the reaction between the substrate complex and aminoacids (glycine, DL-alanine and DL-phenylalanine) were prepared by mixing different molar ratios of reactants viz., $1: 1,1: 2$ and $1: 3$ at $\mathrm{pH} 5.60$ and thermostating the mixture at $50{ }^{\circ} \mathrm{C}$ for 48 hours. The absorption spectra of the resultant solution were recorded using an aqueous ligand solution of appropriate molarity in the reference cell and it was found that all the three product complexes were identical, having a maximum absorption at 406 and $550 \mathrm{~nm}$. The spectra difference between the product complex and substrate complex is shown in Figure 1. 


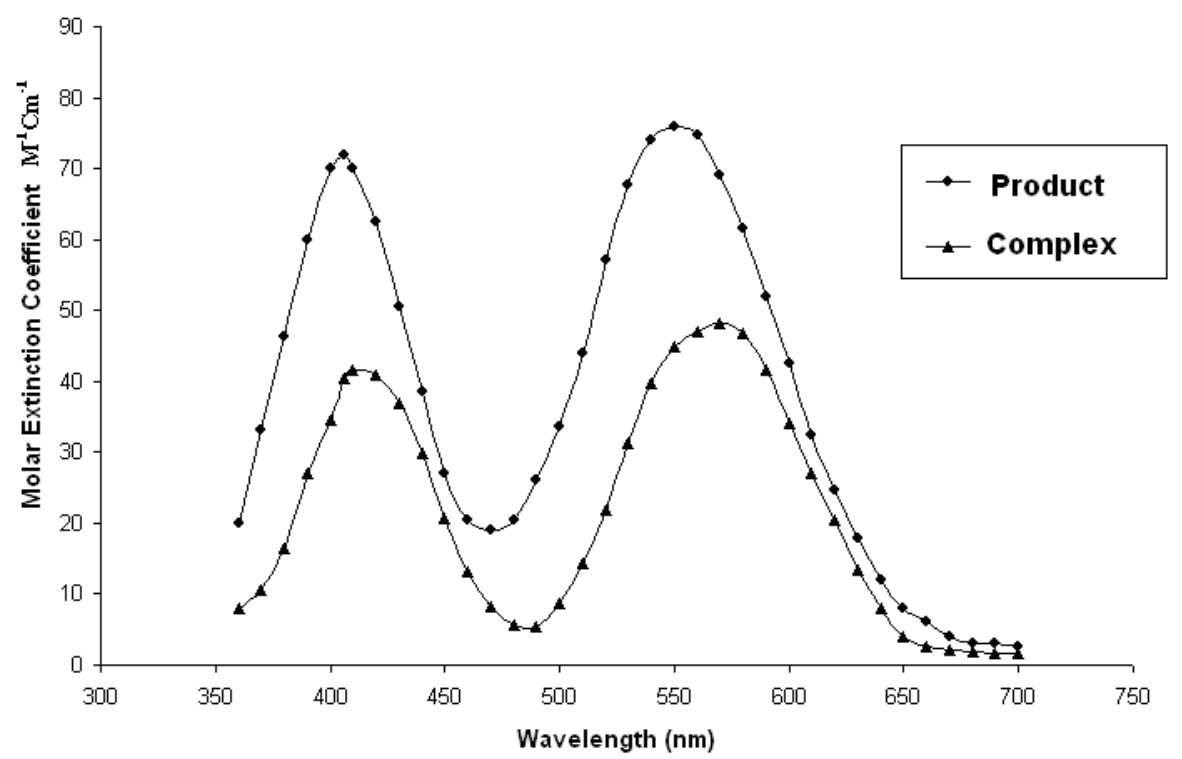

Figure 1. Spectral difference between the complex and the amino acid substituted product $\left[\mathrm{Cr}(\mathrm{mal})_{2}\left(\mathrm{H}_{2} \mathrm{O}\right)_{2}{ }^{-}\right]=4.00 \times 10^{-3} \mathrm{M},[$ amino acid $]=8.00 \times 10^{-2} \mathrm{M}, \mathrm{pH}=5.60$.

\section{Kinetic studies}

The progress of the reaction is monitored by the absorbance measurements for the product at different intervals of time with a MILTON ROY Spectronic 1201 UV visible spectrophotometer (USA). Temperature control in these studies was achieved by the use of thermostat with circulating pump attachment enabling the control of the reaction vessel temperature \pm 0.1 ${ }^{\circ} \mathrm{C}$. Measurement of $\mathrm{pH}$ were carried out with the help of a Systronics digital $\mathrm{pH}$ meter (model 335 , India) with an accuracy of \pm 0.01 . The $\mathrm{pH}$ is adjusted by adding one percent $(\mathrm{v} / \mathrm{v})$ perchloric acid solution. The ionic strength of the reaction medium was adjusted by addition of sodium perchlorate. Required quantities of amino acid (using the stock solutions of $0.25 \mathrm{M}$ of glycine and DL-alanine and 0.1 M of DL-phenyl alanine) and sodium perchlorate (using 4.0 M stock) solutions were taken in to a beaker and then $\mathrm{pH}$ was adjusted (to a particular value) and were taken into a stoppered containers and they were thermostated to attain the experimental temperature, and also the substrate (metal complex) and distilled water was kept at that temperature. A known quantity of the metal complex (from $0.05 \mathrm{M}$ stock) solution was added and contents were diluted to a definite volume with distilled water. Conventional mixing technique was followed and a portion of the reaction mixture was transferred to an optical cell placed in the cell compartment of spectrophotometer. The rate of the reaction was monitored by measuring the absorbance at $530 \mathrm{~nm}$. The reaction was followed up to $80-90 \%$ completion. The absorbance reading at infinite time $\mathrm{A}_{\infty}$ was obtained, keeping the reaction mixture long enough for the reaction to be complete. The rate constants were evaluated by using software KINTOB [30-31] procedure. The substitution reaction was studied as a function of the concentration of amino acids, $\mathrm{pH}$ and substrate. The kinetic runs were also performed at different temperatures. 


\section{RESULTS AND DISCUSSION}

Effect of concentration of amino acids

The pseudo-first order rate constants were evaluated from the straight line plot of $\log \left(A_{\infty}-A_{t}\right)$ vs. time by using KINTOB software procedure The rate of the reaction increases with increase in the concentration of amino acids (Table 1). In the amino acid variation studies the $\mathrm{pH}$ was kept constant by the addition of perchloric acid. A typical plot of $\mathrm{k}_{\mathrm{obs}}$ vs. [glycine] (Figure 2) is linear with an intercept on the rate axis, suggesting that the reaction proceeds by two paths: amino acid dependent and amino acid independent. The slope and intercept values for each straight line in Figure 2 were calculated and the values of slopes at the temperatures of $45.0^{\circ} \mathrm{C}, 50.0^{\circ} \mathrm{C}$ and $55.0^{\circ} \mathrm{C}$, respectively, are $\left(0.625 \times 10^{-3} \mathrm{M}^{-1} \mathrm{~s}^{-1}, 0.714 \times 10^{-3} \mathrm{M}^{-1} \mathrm{~s}^{-1}\right.$ and $\left.1.00 \times 10^{-3} \mathrm{M}^{-1} \mathrm{~s}^{-1}\right)$ and the intercepts $\left(0.55 \times 10^{-4} \mathrm{~s}^{-1}, 0.88 \times 10^{-4} \mathrm{~s}^{-1}\right.$ and $\left.1.20 \times 10^{-4} \mathrm{~s}^{-1}\right)$. The same type of plots was also observed in the case of DL-alanine and DL-phenyl alanine.

Table 1. Variation of rate constants with [glycine], [DL-alanine] and [DL-phenyl alanine].

\begin{tabular}{|c|c|c|c|c|c|c|c|c|c|c|c|}
\hline \multicolumn{4}{|c|}{$\begin{array}{c}\text { With [glycine] } \\
{\left[\mathrm{Cr}(\mathrm{mal})_{2}\left(\mathrm{H}_{2} \mathrm{O}\right)_{2}{ }^{-}\right]=4.0 \times 10^{-3} \mathrm{M}} \\
\mathrm{pH}=5.60, \mu=1.0 \mathrm{M}\end{array}$} & \multicolumn{4}{|c|}{$\begin{array}{c}\text { With [DL-alanine }] \\
{\left[\mathrm{Cr}(\mathrm{mal})_{2}\left(\mathrm{H}_{2} \mathrm{O}\right)_{2}{ }^{-}\right]=4.0 \times 10^{-3} \mathrm{M}} \\
\mathrm{pH}=5.60, \mu=1.0 \mathrm{M}\end{array}$} & \multicolumn{4}{|c|}{$\begin{array}{c}\text { With [DL-phenylalanine] } \\
{\left[\mathrm{Cr}(\mathrm{mal})_{2}\left(\mathrm{H}_{2} \mathrm{O}\right)_{2}^{-}\right]=2.0 \times 10^{-3} \mathrm{M}} \\
\mathrm{pH}=5.60, \mu=1.0 \mathrm{M}\end{array}$} \\
\hline \multirow[b]{2}{*}{$\begin{array}{r}\text { [Glycine] } \\
\times 10^{2}(\mathrm{M})\end{array}$} & \multicolumn{3}{|c|}{$\mathrm{k}_{\mathrm{obs}} \times 10^{4} \mathrm{~s}^{-1}$} & \multirow[b]{2}{*}{$\begin{array}{c}{[\mathrm{DL} \text { - alanine }]} \\
\times 10^{2}(\mathrm{M})\end{array}$} & \multicolumn{3}{|c|}{$\mathrm{k}_{\mathrm{obs}} \times 10^{4} \mathrm{~s}^{-1}$} & \multirow[b]{2}{*}{$\begin{array}{l}\text { [DL-phenylalanine] } \\
\quad \times 10^{2}(\mathrm{M})\end{array}$} & \multicolumn{3}{|c|}{$\mathrm{k}_{\mathrm{obs}} \times 10^{4} \mathrm{~s}^{-1}$} \\
\hline & $\begin{array}{c}45.0 \\
{ }^{\circ} \mathrm{C}\end{array}$ & $\begin{array}{l}50.0 \\
{ }^{\circ} \mathrm{C}\end{array}$ & $\begin{array}{c}55.0 \\
{ }^{\circ} \mathrm{C}\end{array}$ & & $\begin{array}{l}45.0 \\
{ }^{\circ} \mathrm{C}\end{array}$ & $\begin{array}{c}50.0 \\
{ }^{\circ} \mathrm{C}\end{array}$ & $\begin{array}{c}55.0 \\
{ }^{\circ} \mathrm{C}\end{array}$ & & $\begin{array}{l}45.0 \\
{ }^{\circ} \mathrm{C}\end{array}$ & $\begin{array}{c}50.0 \\
{ }^{\circ} \mathrm{C}\end{array}$ & $\begin{array}{c}55.0 \\
{ }^{\circ} \mathrm{C}\end{array}$ \\
\hline 2.0 & 0.67 & 1.02 & 1.41 & 2.0 & 0.79 & 1.12 & 1.60 & 1.0 & 0.70 & 1.03 & 1.48 \\
\hline 4.0 & 0.79 & 1.18 & 1.62 & 4.0 & 1.01 & 1.34 & 2.05 & 1.5 & 0.81 & 1.13 & 1.65 \\
\hline 6.0 & 0.88 & 1.28 & 1.79 & 6.0 & 1.14 & 1.69 & 2.51 & 2.0 & 0.92 & 1.27 & 1.83 \\
\hline 8.0 & 0.98 & 1.44 & 1.98 & 8.0 & 1.32 & 2.08 & 2.99 & 2.5 & 1.01 & 1.38 & 1.98 \\
\hline 10.0 & 1.14 & 1.59 & 2.21 & 10.0 & 1.51 & 2.47 & 3.41 & 3.0 & 1.12 & 1.52 & 2.15 \\
\hline 12.0 & 1.38 & 1.73 & 2.39 & 12.0 & 1.84 & 2.84 & 3.83 & --- & --- & --- & \\
\hline
\end{tabular}

\section{Effect of $p H$}

The concentration of substrate and amino acid were kept constant and the $\mathrm{pH}$ was varied. The rate of the reaction increases with increase in $\mathrm{pH}$ (Table 2). A plot of $\mathrm{pK}$ vs. $\mathrm{pH}$ gives a straight line with a slope less than unity indicating the involvement of $\mathrm{H}^{+}$in the equilibrium step.

Table 2. Variation of rate constants with $\mathrm{pH}$.

\begin{tabular}{|c|c|c|c|c|c|c|c|c|c|c|c|}
\hline \multicolumn{4}{|c|}{$\begin{array}{c}{\left[\mathrm{Cr}(\mathrm{mal})_{2}\left(\mathrm{H}_{2} \mathrm{O}\right)_{2}\right]=4.0 \times 10^{-3} \mathrm{M}} \\
\text { [glycine] }=8.0 \times 10^{-2} \mathrm{M}, \\
\mu=1.0 \mathrm{M}\end{array}$} & \multicolumn{4}{|c|}{$\begin{array}{c}{\left[\mathrm{Cr}(\mathrm{mal})_{2}\left(\mathrm{H}_{2} \mathrm{O}\right)_{2}{ }^{-}\right]=4.0 \times 10^{-3} \mathrm{M}} \\
{[\text { DL-alanine }]=8.0 \times 10^{-2} \mathrm{M}} \\
\mu=1.0 \mathrm{M}\end{array}$} & \multicolumn{4}{|c|}{$\begin{array}{c}{\left[\mathrm{Cr}(\mathrm{mal})_{2}\left(\mathrm{H}_{2} \mathrm{O}\right)_{2}{ }^{-}\right]=2.0 \times 10^{-3} \mathrm{M}} \\
{[\mathrm{DL} \text {-phenylalanine }]=2.0 \times 10^{-2} \mathrm{M}} \\
\mu=1.0 \mathrm{M}\end{array}$} \\
\hline \multirow{2}{*}{ pH } & \multicolumn{3}{|c|}{$\mathrm{k}_{\mathrm{obs}} \times 10^{4} \mathrm{~s}^{-1}$} & \multirow{2}{*}{ H } & \multicolumn{3}{|c|}{$\mathrm{k}_{\mathrm{obs}} \times 10^{4} \mathrm{~s}^{-1}$} & \multirow{2}{*}{$\mathrm{pH}$} & \multicolumn{3}{|c|}{$\mathrm{k}_{\mathrm{obs}} \times 10^{4} \mathrm{~s}^{-1}$} \\
\hline & $45.0^{\circ} \mathrm{C}$ & $50.0^{\circ} \mathrm{C}$ & 55 & & $45.0^{\circ} \mathrm{C}$ & $50.0^{\circ} \mathrm{C}$ & $\mathrm{C}$ & & $5.0^{\circ} \mathrm{C}$ & $50.0^{\circ} \mathrm{C}$ & $55.0^{\circ} \mathrm{C}$ \\
\hline .40 & & & & & & & & & & & \\
\hline & & & & & & & & & & & \\
\hline & & & & & & & & & & & \\
\hline & & & & & & & & & & & \\
\hline & & & & & & & 3.76 & & & & \\
\hline & & & & 6. & & & 4.21 & & & & \\
\hline 30 & 2.19 & 2.87 & 3.91 & 6.80 & 2.32 & 3.82 & 4.89 & 6.80 & 1.71 & 2.21 & 3.32 \\
\hline
\end{tabular}




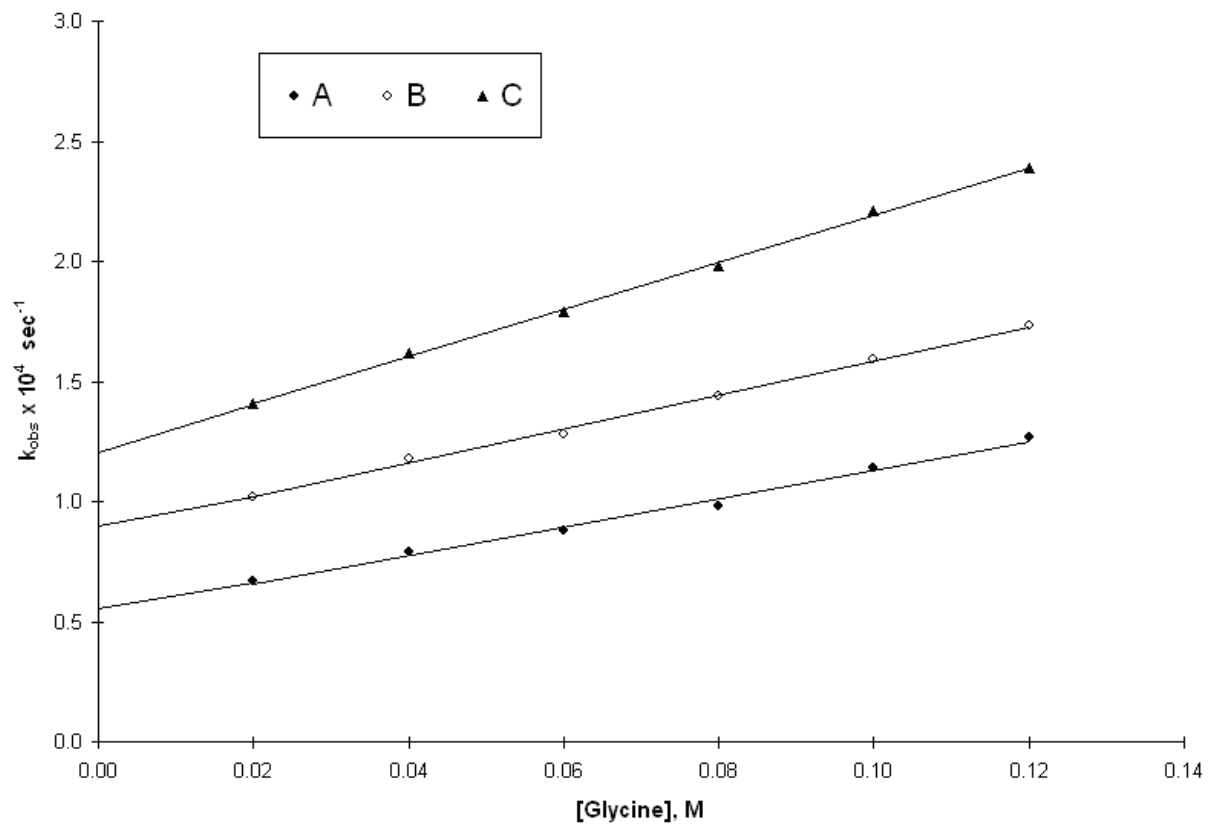

Figure 2. Typical plot of rate constant vs concentration of glycine. $\mathrm{A}=45.0^{\circ} \mathrm{C}, \mathrm{B}=50.0^{\circ} \mathrm{C}$ and $\mathrm{C}=55.0^{\circ} \mathrm{C} .\left[\mathrm{Cr}(\mathrm{mal})_{2}\left(\mathrm{H}_{2} \mathrm{O}\right)_{2}^{-}\right]=4.00 \times 10^{-3} \mathrm{M}, \mathrm{pH}=5.60$.

\section{Effect of substrate}

In this kinetic study at $\mathrm{pH} 5.60$, keeping the constant concentration of amino acids (glycine, DLalanine and DL-phenyl alanine) and varying the concentration of metal complex, the rate constants are evaluated. From this it can be observed that the concentration of the substrate (metal complex) does not have any effect on the rate constant, showing thereby the order with respect to substrate is unity.

\section{Spectrophotometric studies}

When cis-bis(malonato)diaquochromate(III) was taken and different amounts of sodium hydroxide were added, the solution retained its purple colour till the $\mathrm{pH}$ value reached to 6.00 . Beyond this $\mathrm{pH}$ the solution turned to different shade of green. Spectra of cisbis(malonato)diaquochromate(III) $[0.004 \mathrm{M}]$ were recorded at different $\mathrm{pH}$ values by adding different quantities of $0.01 \mathrm{M} \mathrm{NaOH}$ solution. From the Figure 3 it can be noted that the peak at longer wavelength exhibits a bathochromic shift with an increase in the molar extinction coefficient. The peak at shorter wavelength is not altered but the molar extinction coefficient increases with increasing $\mathrm{pH}$. These observations indicate the gradual formation of hydroxy species of the substrate in the experimental $\mathrm{pH}$ range. Further there is an increase in the formation of hydroxy species with increase in $\mathrm{pH}$ leading to a proportionate increase in the overall rate and gradual formation of species of the type $\mathrm{Cr}(\mathrm{mal})_{2}\left(\mathrm{H}_{2} \mathrm{O}\right)(\mathrm{OH})^{2-}$. 


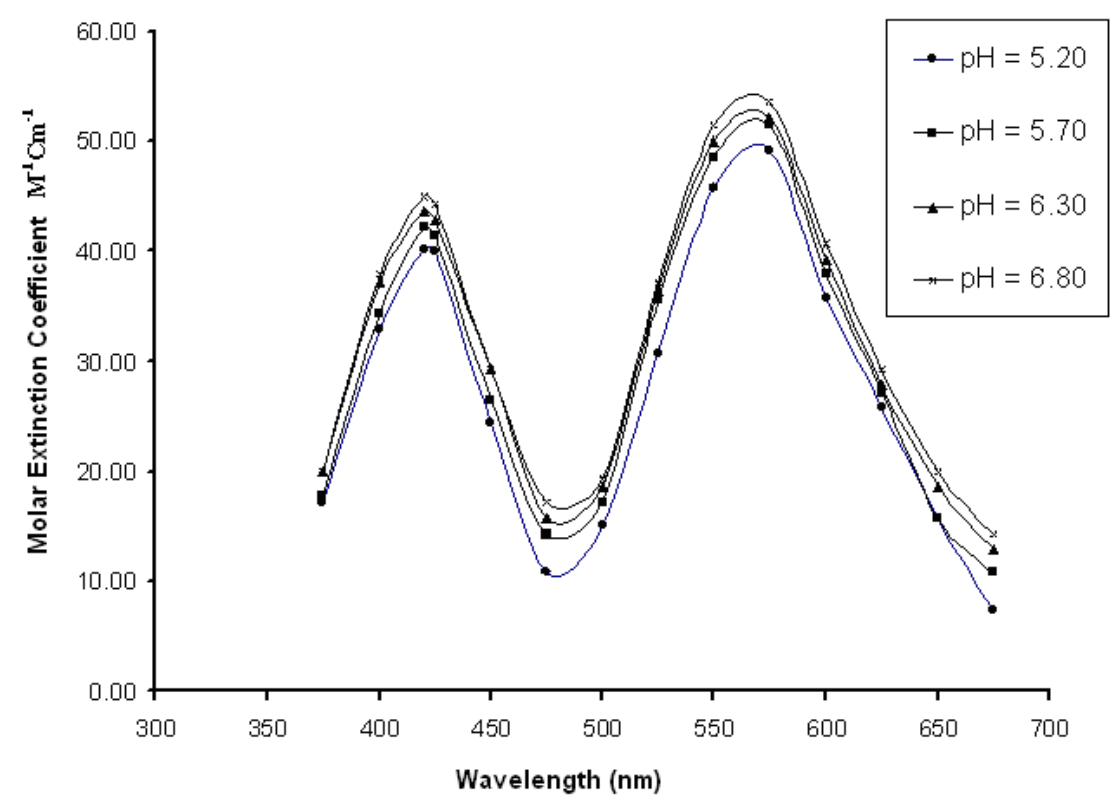

Figure 3. Absorption spectra of cis-bis(malonato)diaquochromate(III) at different $\mathrm{pH}$ values. $\left[\mathrm{Cr}(\mathrm{mal})_{2}\left(\mathrm{H}_{2} \mathrm{O}\right)_{2}^{-}\right]=4.00 \times 10^{-3} \mathrm{M}$.

Although the substitution reactions at chromium(III) centres are well studied, a little information is available with amino acids as ligands. In the case of substitution of cisbis(oxalato)diaquochromate(III) with amino acids such as glycine, DL-alanine and DLphenylalanine forms a maroon coloured complex [27] whose spectra with an absorption maxima at $406 \mathrm{~nm}\left(\varepsilon=90.75 \mathrm{M}^{-1} \mathrm{~cm}^{-1}\right)$ and $550 \mathrm{~nm}\left(\varepsilon=80.7 \mathrm{M}^{-1} \mathrm{~cm}^{-1}\right)$ is an agreement with the observation made and reported by Kallen and Hamm [32] for $\mathrm{Cr}(\mathrm{OX})_{2}(\mathrm{gly})^{2-}$. This indicates that the two water molecules in $\mathrm{Cr}(\mathrm{OX})_{2}\left(\mathrm{H}_{2} \mathrm{O}\right)_{2}{ }^{-}$are replaced by glycine and the oxalate molecules are intact and they do not take part in the substitution process indicating that aquation does not take place under experimental conditions. The substitution of cis-bis(malonato)diaquochromate(III) with amino acids (glycine, DL-alanine and DL-phenyl alanine) also forms a maroon coloured product complex with an absorption maxima at $406 \mathrm{~nm}$ and $550 \mathrm{~nm}$.

The similar observations are made in the case of cis-bis(malonato)diaquochromate(III) with glycine, so the two water molecules in $\mathrm{Cr}\left(\mathrm{mal}_{2} \mathrm{C}_{2} \mathrm{O}\right)_{2}{ }^{-}$are replaced by glycine and the malonate molecules are intact and they do not take part in the substitution process indicating that aquation does not take place under experimental conditions. Further the studies at $\mathrm{pH} 3.0$ indicate that the reaction does not occur even after at a lapse of few days which support that the malonato groups in the complex are intact and aquation does not take place [leading to the formation mono(malonato)tetraaquochromium(III)] or the formation of glycinato complex. Analogous product species are envisaged in the case of DL-alanine and DL-phenylalanine in this substitution reaction.

In the octahedral substitution reactions mainly two important effects operate viz., cis and trans effect. Under the experimental conditions the cis effect operates in the $\mathrm{pH}$ range 5.40-6.80 and 7.40-8.80. On the other hand trans effect predominates at higher $\mathrm{pH}(>11.00)$. 
Further an attempt was made to identify the nature of the product species ( $\mathrm{pH} 8.00$ to 11.00 ) with different substrates of chromium(III) and amino acids as ligands by spectral and ion exchange studies. These studies support the formation of the product species of the type $\mathrm{Cr}(\mathrm{gly})(\mathrm{OH})_{4}\left(\mathrm{H}_{2} \mathrm{O}\right)^{2-} / \mathrm{Cr}(\mathrm{gly})(\mathrm{OH})_{3}\left(\mathrm{H}_{2} \mathrm{O}\right)_{2}{ }^{-}$at $\mathrm{pH}$ 11.00. On the other hand in the experimental $\mathrm{pH}$ range, the malonate group does not appear to dislodge from the chromium(III) centre resulting in formation of the species of the type $\mathrm{Cr}(\mathrm{mal})_{2}(\mathrm{gly})^{2-}$.

\section{Proposed mechanism}

Under the experimental conditions the amino acids exists as Zwitter ion [33]. On the basis of the experimental observations the following mechanism is proposed for the substitution process.

Amino acid (AA) dependent path:

$\mathrm{Cr}(\mathrm{mal})_{2}\left(\mathrm{H}_{2} \mathrm{O}\right)_{2}^{-}+\mathrm{H}_{2} \mathrm{O} \stackrel{\mathrm{K}}{\leftrightarrows} \mathrm{Cr}(\mathrm{mal})_{2}\left(\mathrm{H}_{2} \mathrm{O}\right)(\mathrm{OH})^{2-}+\mathrm{H}_{3} \mathrm{O}^{+}$

$\mathrm{Cr}(\mathrm{mal})_{2}\left(\mathrm{H}_{2} \mathrm{O}\right)(\mathrm{OH})^{2-}+\mathrm{AA} \stackrel{\mathrm{k}_{1}}{\rightarrow} \mathrm{Cr}(-\mathrm{mal})(\mathrm{mal})\left(\mathrm{H}_{2} \mathrm{O}\right)(\mathrm{OH})(\mathrm{AA})$ rate determining

fast

$\mathrm{Cr}(-\mathrm{mal})(\mathrm{mal})\left(\mathrm{H}_{2} \mathrm{O}\right)(\mathrm{OH})(\mathrm{AA}) \rightarrow$ Products

where AA represents amino acid (glycine/DL-alanine/DL-phenylalanine).

Amino acid (AA) independent path:

$\mathrm{k}_{2}$

$\mathrm{Cr}(\mathrm{mal})_{2}\left(\mathrm{H}_{2} \mathrm{O}\right)_{2}{ }^{-} \rightarrow \mathrm{Cr}(-\mathrm{mal})(\mathrm{mal})\left(\mathrm{H}_{2} \mathrm{O}\right)_{2}{ }^{-}$ rate determining

$\mathrm{Cr}(-\mathrm{mal})(\mathrm{mal})\left(\mathrm{H}_{2} \mathrm{O}\right)_{2}^{-}+\mathrm{AA} \stackrel{\text { fast }}{\rightarrow}$ Products

where (-mal) represents single ended malonate (in ligand independent path a single ended malonate is envisaged [34]).

Reaction (1) is an equilibrium step involving $\mathrm{H}^{+}$ion suggesting the dependence of the rate on hydrogen ion. Reaction (2) is a rate determining step, which in a further fast step leads to the formation of product. Equation (1), (2) and (3) and the experimental data, lead to the following rate law for the reaction.

Rate $=\mathrm{k}_{1}\left[\mathrm{Cr}(\mathrm{mal})_{2}\left(\mathrm{H}_{2} \mathrm{O}\right)(\mathrm{OH})^{2-}\right][\mathrm{AA}]+\mathrm{k}_{2}\left[\mathrm{Cr}(\mathrm{mal})_{2}\left(\mathrm{H}_{2} \mathrm{O}\right)_{2}{ }^{-}\right]$

$$
\text { But } \mathrm{K}=\frac{\left[\mathrm{Cr}(\mathrm{mal})_{2}\right.}{\left[\mathrm{C} r(m a l)_{2}\left(\mathrm{H}_{2} \mathrm{O}\right)_{2}^{-}\right]} \frac{\left.\left(\mathrm{H}_{2} \mathrm{O}\right)(\mathrm{OH})^{2-}\right]\left[\mathrm{H}_{3} \mathrm{O}^{+}\right]}{[\mathrm{C}(\mathrm{O})}
$$

On substituting $\frac{K\left[\mathrm{Cr}(\mathrm{mal})_{2}\left(\mathrm{H}_{2} \mathrm{O}\right)_{2}^{-}\right]}{\left[\mathrm{H}_{3} \mathrm{O}^{+}\right]}$for $\left[\mathrm{Cr}(\mathrm{mal})_{2}\left(\mathrm{H}_{2} \mathrm{O}\right)(\mathrm{OH})^{2-}\right]$ in equation 5

Rate $=\frac{K k_{1}\left[\mathrm{Cr}(\mathrm{mal})_{2}\left(\mathrm{H}_{2} \mathrm{O}\right)_{2}^{-}\right][\mathrm{AA}]}{\left[\mathrm{H}_{3} \mathrm{O}^{+}\right]}+k_{2}\left[\mathrm{Cr}(\mathrm{mal})_{2}\left(\mathrm{H}_{2} \mathrm{O}\right)_{2}^{-}\right]$ 
At a constant $\mathrm{pH}$ the equation 6 transforms to

Rate $=\mathrm{k}^{\prime}\left[\mathrm{Cr}(\mathrm{mal})_{2}\left(\mathrm{H}_{2} \mathrm{O}\right)_{2}^{-}\right][\mathrm{AA}]+\mathrm{k}^{\prime \prime}\left[\mathrm{Cr}(\mathrm{mal})_{2}\left(\mathrm{H}_{2} \mathrm{O}\right)_{2}^{-}\right]$

Where $\mathrm{k}^{\prime}=\frac{\mathrm{Kk}_{1}}{\left[\mathrm{H}_{3} \mathrm{O}^{+}\right]}$and $\mathrm{k}^{\prime \prime}=\mathrm{k}_{2}$

For convenience $\mathrm{k}_{2}$ is put as $\mathrm{k}^{\prime \prime}$

From the equation (7) it can be seen that a plot of observed rate constant vs. the concentration of the ligand (AA) at a constant $\mathrm{pH}$ should be linear whose slope is $\mathrm{k}^{\prime}$ and the intercept $\mathrm{k}$ ".

\section{REFERENCES}

1. Krishna Murthy, K.V.; Haris, G.M. Chem. Rev. 1961, 61, 213.

2. Ashley, K.R.; Hamm, R.E. Inorg. Chem. 1966, 5, 1645.

3. Kulprathi Panja, S.; Ashley, K.R. J. Inorg. Nucl. Chem. 1970, 32, 3565.

4. Casula, M.; Illuminati, G.; Ortaggi, G. J. Inorg. Nucl. Chem. 1972, 11, 444.

5. Ashley, K.R.; Lamba, R.S. Inorg. Chem. 1974, 13, 2117.

6. Hamm, R.E. J. Am. Chem. Soc. 1953, 75, 609.

7. Mertz, W. Physiol. Rev. 1969, 49, 163.

8. Mertz, W. Science 1981, 213, 1332.

9. Mertz, W.; Toepfer, E.W.; Roginski, E.E.; Polansky, M.M. Fed. Proc., Fed. Am. Soc. Exp. Biol. 1974, 33, 2275.

10. Anderson, R.A.; Mertz, W. Sci. Total Environ. 1981, 17, 13.

11. Anderson, R.A. Proc. Chromate Symp., Industrial Health Foundation Inc. 1981, 333.

12. Cranfield, W.K.; Diosy, R. Diabetes 1975, 24, 106.

13. Banerjea, D.; Dutta Chaudhuri, S. J. Inorg. Nucl. Chem. 1968, 30, 871.

14. Khan, I.A.; Kabir-ud-din J. Inorg. Nucl. Chem. 1981, 43, 1082.

15. Abdullah, M.A.; Barett, J.; Brien, P. J. Chem. Soc. Dalton Trans. 1984, 1647.

16. Subrahmanyam, D.; Anata Ramam, V. J. Indian Council Chemists 1997, 14, 40.

17. Ramasami, T.; Taylor, R.S.; Sykes, A.G. Inorg. Chem. 1976, 15, 2318.

18. Niogy, B.K.; De, G.S. Proc. Indian. Acad. Sci. (Chem. Sci.) 1983, 92, 153.

19. Niogy, B.K.; De, G.S. J. Indian Chem. Soc. 1984, 65, 389.

20. Mitra (Mazumdar), S.; De, K. Proc. Indian Acad. Sci. (Chem. Sci.) 1989, 101, 187.

21. Mitra, S.; De, K. J. Indian Chem. Soc. 1990, 16, 67.

22. Khan, I.A.; Sahid, M.; Kabir-ud-din Indian J. Chem. 1983, 22A, 382.

23. Khan, A.I.; Kabir-ud-din Indian J. Chem. 1984, 23A, 98.

24. Kabir-ud-din; Khan, G.J.; Jilani, G. Ann. Chim. (Rome) 1985, 75, 279.

25. Kabir-ud-din; Khan, G.J. J. Coord. Chem. 1992, 26, 351.

26. Kabir-ud-din; Khan, G.J.; Khan, Z.; Rafiquee, Md.Z.A. J. Chem. Research (S) 1996, 178.

27. Subba Rao, M.V.; Ananta Ramam, V.; Muralidhara Rao, V. Afr. J. Sci. Technol. (AJST) communicated.

28. Chang, J.C. J. Inorg. Nucl. Chem. 1968, 30, 945.

29. Olson, M.V.; Behnke, C.E. Inorg. Chem. 1974, 13, 1329.

30. Nageswarao, G.; Ananta Ramam, V.; Satyanarayana Rao, S.V.V.; Sambasiva Rao, R. J. Indian Chem. Soc. 1998, 75, 236.

31. Ananta Ramam, V.; Nageswara Rao, G.; Sambasiva Rao, R. Indian J. Chem. 1997, 36A, 964.

32. Kallen, T.W.; Hamm, R.E. Inorg. Chem. 1977, 16, 1147.

33. Voet, D.; Voet, J.G.; Biochemistry, John Wiley and Sons: New York; 1990; chapter II, p 59. 34. Chang, J.C. Inorg. Nucl. Chem. Lett. 1969, 5, 587. 